\title{
When Extremism Pays: Policy Positions, Voter Certainty, and Party Support in Postcommunist Europe
}

\author{
Lawrence Ezrow University of Essex \\ Jonathan Homola Washington University in St. Louis \\ Margit Tavits Washington University in St. Louis
}

\begin{abstract}
We argue that extreme positioning benefits parties in new democracies, because-given the lack of other reliable cues such as party histories - the distinctiveness of their left-right policy positions increases voter certainty about parties' identities and intentions in office. Cross-sectional analyses provide evidence that, in the new democracies of postcommunist Europe, parties that are farther away from the mean voter position gain more popular support than those moderately positioned along a policy continuum. In established democracies, by contrast, policy moderation increases popular support. We also find empirical support for the proposed causal mechanism that links policy positions to popular support via voter certainty. These findings have implications for party strategies, spatial theories, and our understanding of political representation in new democracies.
\end{abstract}

E xisting cross-national research suggests that parties gain votes by adopting positions close to the mean (or median) voter's position (Alvarez, Nagler, and Bowler 2000a; Alvarez, Nagler, and Willette 2000b; Dow 2001, 2011; Schofield 2004; see also Schofield, Sened, and Nixon 1998a; Schofield et al. 1998b). ${ }^{1}$ In this article, we argue that this relationship is less likely to hold in new democracies, where parties are, instead, more likely to be rewarded for extremism than centrism. Our argument, which we detail in the next section, builds on three central premises derived from the existing literature. First, parties with less ambiguous positions (i.e., positions about which voters, on average, are more certain) attract more electoral support. Second, centrist positions generate more ambiguity and voter uncertainty than noncentrist positions. Third, noncentrist or extremist positions are particularly effective in reducing voter uncertainty when other cues about party identities and intentions are absent, as is the case in new democracies.

In order to test our argument, we conduct a macrolevel analysis of party positioning and election outcomes across 31 countries from 1996 to $2007 .^{2}$ Our study produces the following findings. First, with respect to the established democracies, we corroborate the findings of the existing studies of multiparty competition that parties receive a statistically significant electoral benefit from locating near the mean voter position. Second, in line with our theoretical expectation, we find that in the context of new, postcommunist democracies, parties receive an

\footnotetext{
${ }^{1}$ Margit Tavits acknowledges funding from the Weidenbaum Center. An online appendix with supplementary material for this article is available at http://dx.doi.org/10.1017/S0022381613001461. Data and replication materials are available at http://privatewww.essex.ac.uk/ $\sim$ ezrow/.

${ }^{2}$ This macrolevel approach has been used extensively in empirical studies of the electoral effects of candidates' and parties' positioning in the United States (Ansolabehere, Snyder, and Stewart 2001; Burden 2001; Canes-Wrone, Brady, and Cogan 2002; Erikson, MacKue, and Stimson 2002), the United Kingdom (Nagel and Wlezien 2010), and across 12 West European democracies (Ezrow 2005, 2010), as well as in studies of the electoral effects of economic conditions both inside and outside of the United States (Lewis-Beck 1988; Powell 2000; Powell and Whitten 1993). Ours is the first study to extend this approach to the analysis of party competition in new, postcommunist democracies.
} 
electoral benefit when they adopt distinctly noncentrist (i.e., extremist) policy positions. Third, we also find support for our causal mechanism by showing that (1) voters in both types of democracies prefer not to support parties whose positions are uncertain, and (2) in postcommunist countries, voters are more certain of the ideological stances of extreme than moderate parties. By contrast, this relationship between party position and voter certainty is much weaker in established democracies where well-known party profiles already exist for moderate parties.

Our findings highlight the importance of voter certainty about party positions in explaining electoral outcomes. They further suggest that the spatial modeling framework helps us understand electoral competition not only in advanced but also in newer democracies (see also Rohrschneider and Whitefield 2009). More specifically, our results have important implications for party strategies in relatively new democracies (Budge 1994; Laver 2005; see also Budge, Ezrow, and McDonald 2010). In these democraciescharacterized by unstable party systems (Birch 2003; Powell and Tucker 2013; Rose and Mishler 2010; van Biezen 2003; Tavits 2005), uncertainty about how election outcomes are translated into governing coalitions (Druckman and Roberts 2007; Grzymala-Busse 2001; Tzelgov 2011), and uncertainty about how governing coalitions formulate policy—citizens reward parties that present extreme party positions, because these parties are more successful at communicating clear policy stances than moderate parties. Given this, parties that want to maximize vote share are better off by adopting distinctly noncentrist policy positions in these systems.

\section{Party Positions and Voter Support: Theoretical Expectations}

Existing literature on the electoral consequences of party positioning has mostly focused on advanced democracies. In this context, macrolevel research looking at parties' vote shares in real-world multiparty elections concludes that parties typically gain votes when they are positioned closer to the center of the voter distribution (Ezrow 2005). ${ }^{3}$ Most simulationbased empirical studies using individual-level survey data from real-world multiparty elections agree that

\footnotetext{
${ }^{3}$ Niche parties, i.e., parties belonging to the Green, Communist, and the extreme-right Nationalist party families, are the exception (see Ezrow 2010).
}

centrist party positioning would increase popular support (Alvarez, Nagler, and Bowler 2000a; Alvarez, Nagler, and Willette 2000b; Schofield, Sened, and Nixon 1998a; Schofield et al. 1998b). These findings are in line with the traditional spatial model of twoparty electoral competition that predicts convergent party behavior (Downs 1957; Enelow and Hinich 1984) and with the theoretical models that assume probabilistic voting according to which parties maximize their vote shares by moderating their ideological policy programs in multiparty systems (e.g., Lin, Enelow, and Dorussen 1999). ${ }^{4}$

In this article, we argue that a similar relationship between policy moderation and vote maximization is less likely to exist in new democracies. Rather, we argue that, all other things equal, in these countries it is the distinctly noncentrist party positions that attract more support. This expectation is based on three specific arguments, each of which we will elaborate on below. First, the higher the voter uncertainty about a party's position, the less electoral support is it able to attract. Second, the more centrist the policy position of a party, the more difficult it is for voters to discern what the party actually stands for. Conversely, the more distinct (noncentrist) a party position, the clearer its message and the easier it is for voters to identify its position. Third, extreme party positioning on a left-right scale is an especially potent signal that helps to decrease ambiguity and voter uncertainty about party positioning. It is likely to be most powerful in low-information environments present in new democracies due to the lack of long-established party reputations that otherwise would provide cues to voters about parties' general policy profiles.

\section{Uncertainty Repels Voters}

The argument that voter support is lower for the parties whose positions are uncertain builds directly on the literature on information and elections (Alvarez 1998; Bartels 1986; Enelow and Hinich 1984; Franklin 1991; Hinich and Munger 1997; Koch 2003; Page 1976, 1978). Specifically, Alvarez argues that "with high uncertainty the voter has a difficult time discerning

\footnotetext{
${ }^{4}$ This position, however, is somewhat contested. For example, the formal theoretical models that assume deterministic voting predict noncentrist party behavior (Cox 1990; see also Adams 2001), and some simulation-based studies conclude that parties would maximize votes by presenting distinctly noncentrist positions (Adams and Merrill 1999, 2000). Still other studies highlight the relevance of valence characteristics in determining whether centrist or noncentrist positioning is going to be more electorally beneficial (Schofield 2004; Schofield and Sened 2006).
} 
where in the issue space the candidate's position may be" $(1998,31)$. He introduces this uncertainty into the standard spatial model and demonstrates that "under the assumption that voters are risk-averse (implied by the assumption that voter utility functions are singlepeaked and concave), perceptual uncertainty depresses the voter's utility for a candidate" (33). Using simulated data, Alvarez further finds that the influence of voter uncertainty on candidate evaluation is substantial ("especially when the candidate is very close to the voter on the issue") and concludes with the following hypothesis: "The greater the individual's uncertainty about the candidate's policy positions, the lower their utility for the candidate and hence the lower their probability of supporting the candidate, all other things held constant" (36). In general, these studies portray voters as risk averse, reluctant to support a candidate or party whose position is uncertain because, depending on the level of uncertainty, the party may actually be quite far from the position that the voter prefers (Koch 2003).

In addition to reluctance, voters may simply not be able to vote for a party based on their policy preferences if they do not know where the party stands (Page 1976, 1978). Alvarez (1998, 36-41) provides a formalization of this proposition as well. Additionally, looking at the level of party systems, Dalton (2008) and Lachat (2008), for example, demonstrate that the extent of ideological voting increases as parties take more divergent positions. If parties are hard to distinguish based on their policy positions, vote choice becomes influenced by other, nonpolicy related (and perhaps random) factors (see also Alvarez 1998).

Finally, uncertainty may also undermine the nonpolicy-related evaluations, i.e., the credibility and competitiveness of a party, by making it look "evasive or spineless" (Campbell 1983, 278). ${ }^{5}$ Media and rival parties can easily reinforce this perception by depicting the party as opportunistic, equivocal, or flip-flopping. All this erodes the valence evaluations of the party and thereby hurts its electoral performance as elegantly shown, both formally and empirically, by Schofield and Sened (2006). Clark (2009) also shows

\footnotetext{
${ }^{5}$ Not all authors agree that uncertainty about party positions repels voters. For example, Tomz and van Houweling (2009), using survey data from the United States, argue the exact opposite. There are also formal studies on strategic ambiguity suggesting that candidates benefit from adopting vague issue positions (e.g., Alesina and Cukierman 1990; Alesina and Holden 2008). These studies, however, are explicitly designed to address the specific context of two-party systems with primaries rather than multiparty competition more broadly.
}

that the effect of valence evaluations on vote choice is comparable to that of policy evaluations.

In sum, voters are less likely to vote for a party whose position is uncertain because it is risky (or even impossible) to cast a policy-based vote for such a party and/or because the party has low valence. Related to these arguments, Hinich and Munger (1997) move the analysis to the party level and show that in the spatial model, uncertainty can cause an extremist to win over a centrist party. This is especially likely if the level of uncertainty (understood as variance around the mean placement guess by voters) about the extremist's position is lower than that of the centrist's position. This brings us to the second part of our argument.

\section{Centrist Positions Generate Uncertainty}

We argue that voters are more likely to be certain about the positions of noncentrist than centrist parties because these positions send clearer and stronger signals about party stances. Hinich and Munger, for example, argue that voters have clearer expectations of what extremists - as opposed to centrists-will actually do while in office. They state that "the cognitive process by which voters form expectations about what candidates will likely do in office... advantages extremists" $(1997,126)$. It is simply harder for a centrist party to offer a similar level of commitment and clarity (see also Hinich and Munger 1994). "Political extremists may be more doctrinally pure and consistent, and therefore have lower perceived variance, than candidates in the middle" (127). Similarly, Rabinowitz and Macdonald, when presenting their directional model of voting, argue that noncentrist positions represent "clear, strong stands" $(1989,98)$, are of high intensity and evoke clear (emotional) responses from voters. Centrist positions, on the other hand, can easily appear ambiguous and of low intensity. ${ }^{6}$

These arguments are in accord with the expectation that voters lack the resources to gather detailed information about party positions, and, therefore, look for simple but fundamental underlying principles that guide party stances (Kitschelt 2000). A noncentrist position is likely to provide a clear signal about such principles. Consider, for example, two parties, A and B. Party A adopts some rightist and some leftist

\footnotetext{
${ }^{6}$ According to Rabinowitz and Macdonald (1989), candidates and parties that want voters to be well-informed of their positions and base judgments about them on these positions will take noncentrist positions. Those that want to remain noncommittal on an issue, and prevent voters from using their position on that issue as the basis for judging the party, will take centrist positions.
} 
positions on specific issues to arrive at an overall centrist platform. Party B, in contrast, takes consistent and high-intensity right-wing positions on all issues. It is easy to see how voters might be more confused about the position of party $\mathrm{A}$ than party $\mathrm{B}$ given the explicit conservatism that underlies the platform of the latter as opposed to the absence of any clear ideological principle underlying the platform of the former.

It is important to note that centrist positions are not just likely to be more ambiguous but they also appear more confusing to voters. This is relevant in so far as uncertainty can result not only from the ambiguity of party positions, but also from the failure of voters to receive or correctly interpret information about an otherwise unambiguous position.

\section{Extremism Reduces Uncertainty in New Democracies}

Finally, we argue that noncentrist position taking is an especially informative signal in new democracies. In particular, our empirical focus will be on the democracies of postcommunist Europe. In new democracies, we argue, the overall level of voter certainty about party positioning is likely to be considerably lower than in advanced democracies because any cues generated by party histories and interactions are absent. Therefore, taking an extreme ideological position can be an especially potent remedy for reducing voter uncertainty about what a given party stands for.

This expectation, again, draws on insights from the literature on information and elections, according to which voters are more likely to be certain about party positions when they are afforded a greater opportunity to learn about parties' ideological orientations (Alvarez 1998; Bartels 1986). Similarly, Koch (2003) argues, citing psychological research, that citizens' certainty judgments may be influenced not only by higher levels of factual information but also by their general familiarity with the party. In accord with this argument, studies show that voters are generally more certain about the placement of incumbents than challengers. Some scholars even argue that the phenomenon of incumbency advantage can, at least partially, be explained by greater voter certainty about incumbents' as opposed to challengers' positions (Bernhardt and Ingberman 1985; Ingberman 1989). Because of the advantage that incumbents enjoy in terms of voter information levels and familiarity, they do not necessarily need to take clear ideological positions to decrease voters' sense of uncertainty. Challengers, or parties that are not well known and whose positions have received little exposure, on the other hand, are likely to take more extreme issue positions (Groseclose 2001), possibly in an attempt to reduce voter uncertainty and thereby compensate for this disadvantage (Koch 2003).

We can translate these arguments into expectations about differences between advanced and new democracies. Voters in old democracies have had a greater opportunity to learn about parties' ideological orientations and are also likely to be generally more familiar with the parties in their system than are voters in new democracies. In the latter case, party systems are young and unstable (Tavits 2005), party organizations are still developing, and direct contacts between voters and parties are limited (Mair and van Biezen 2001; Tavits 2013; van Biezen 2003), and voters have had little opportunity to learn about party ideologies, the democratic process (Mainwaring and Scully 1995; O'Donnell and Schmitter 1986; Tavits and Annus 2006), or even the meaning of the left-right ideological scale. This uncertainty generated by the absence of party histories and voter experience with the democratic process is further exacerbated by party behavior in the region. For example, Tavits and Letki (2009) report how programmatically center-left parties often implement rightist (and center-right parties leftist) policies once in office. Governing coalitions, too, are frequently odd compromises between leftist and rightist parties (Druckman and Roberts 2007; Grzymala-Busse 2001). When in advanced democracies consistent behavior by parties may help clarify their positions, ${ }^{7}$ party behavior in the nonelectoral arena-possibly motivated by alternative strategic considerations (Druckman and Roberts 2007; Grzymala-Busse 2001; Tavits and Letki 2009; Tzelgov 2011)_does not allow for such a possibility. For these reasons, several authors have pointed out that voters in new democracies are more likely to be confused about the ideological differences between parties than voters in advanced democracies (Grzymala-Busse 2006; Rose 1995) and that voter attachments to parties are weaker (Evans and Whitefield 1993; Ezrow, Tavits, and Homola, n.d.).

Given the low-information environment, we argue that centrist positions and fine gradations in party ideologies are likely to be especially confusing and uninformative for voters. In such an environment, where they are unable to rely on contextual cues and experience, voters need other credible and strong signals about party positions. Just as was the case with

\footnotetext{
${ }^{7}$ See especially Fortunato and Stevenson (2013) about the role of coalition participation on the level of voter information about party positions.
} 
informationally disadvantaged challengers discussed above, taking noncentrist positions is likely to provide one such signal. Indeed, because ideological competition and party systems are still developing, scholars have argued that symbolic politics evoking emotions and sentiments is likely to be especially relevant in new democracies (Evans 2006). ${ }^{8}$ More extreme ideological positions are more likely to reach voters because they evoke such emotions (Rabinowitz and Macdonald 1989). Reaching voters, in turn, is likely to decrease their uncertainty about party positions.

Taken together, we have argued that (1) voter support is lower for parties whose positions are uncertain, and (2) a noncentrist position increases voter certainty especially in new democracies. If these arguments hold, then it follows that, in these new democracies, noncentrist policy positions are electorally more beneficial than centrist ones. ${ }^{9}$ As a corollary, parties with extreme positions are likely to attract more votes the higher the general level of voter uncertainty about party positions. In sum, previous literature on the electoral consequences of party positioning in established democracies and our own theorizing about this relationship in new (postcommunist) democracies allows formulating the following two hypotheses:

H1 (The Established Parties Hypothesis): In established democracies, the closer the party is to the mean voter position on the left-right scale, the higher its vote share.

H2 (The Postcommunist Parties Hypothesis): In postcommunist democracies, the closer the party is to the mean voter position on the left-right scale, the lower its vote share.

In addition to these main hypotheses, we will also test two other steps in the proposed causal chain: (1) that voters are, in general (i.e., in all types of democracies), reluctant to vote for parties whose positions are

\footnotetext{
${ }^{8}$ Although primarily focusing on uncovering the structure of party competition in new democracies at the voter level, much of the argumentation in Evans and Whitefield (1993) also implies the importance of clarity of positioning and signaling under conditions of uncertainty in postcommunist countries (see also Evans and Whitefield 2000).

${ }^{9}$ Note that the directional theory of voting (Rabinowitz and Macdonald 1989) reaches a similar conclusion by assuming that voters prefer parties that take high-intensity positions on "their" side of the ideological scale. Their theory does not provide an explicit explanation for such a voting preference. Here, we provide a specific and testable causal mechanism by arguing that voters are likely to prefer the noncentrist parties to the centrist ones because they are more likely to be certain about what the former as opposed to the latter stand for, and it is risky or even impossible for voters to cast a (policy based) vote for a party whose position they cannot determine.
}

unclear, and (2) voters in new (postcommunist) democracies are more likely to be certain about the positions of noncentrist than centrist parties.

\section{Data, Measures, and Method}

To test Hypothesis 1 and Hypothesis 2, we employ the Comparative Study of Electoral Systems (CSES), which allow us to construct measures of the mean citizen policy preference in each country, as well as measures of the policy distances between the parties' positions (as perceived by the citizens) and the mean citizen preference. The measure of our dependent variable-popular support (vote share) - controls for the possibility that successful parties will receive fewer votes in systems where there are more competitive parties. Specifically, we use the Normalized Vote Share calculated as follows:

$$
\text { Normalized vote share }(N V S)=V_{i j} * N_{j} \text {, }
$$

where $V_{i j}$ equals the absolute share of the vote for party $i$ in election $j$ (as reported by the CSES), and $N_{j}$ is the number of parties in election $j$ receiving over $5 \%$ of the vote. ${ }^{10}$

The measure of party policy distance also relies on observations from the CSES. The survey asks respondents in each country to place themselves, and each of their significant national parties, on a left-right scale that ranges from 0 (extreme left) to 10 (extreme right). ${ }^{11}$ The mean voter position in each country election year is computed as the mean response to this item. Party left-right policy positions are calculated as the mean response to a similar item about the left-right position of the national parties competing in an election year. ${ }^{12}$ The party's distance to the mean voter position is measured as the difference between party position and the mean citizen placement:

\footnotetext{
${ }^{10}$ Note that we also conducted additional statistical analyses employing the parties' absolute vote shares and, to address concerns about the bounded nature of vote shares, logged vote shares as dependent variables. These analyses (presented in Tables S2a-S4c of the supplementary appendix) supported the substantive conclusions reported below.

${ }^{11}$ Question wording: "In politics people sometimes talk of left and right. Where would you place yourself on a scale from 0 to 10 where 0 means the left and 10 means the right?"

${ }^{12}$ Specifically, respondents were asked the following question: "In politics people sometimes talk of left and right. Where would you place [PARTY] on a scale from 0 to 10 where 0 means the left and 10 means the right?" The mean value of all responses to this item in a given election survey constitutes the overall left-right policy stance of the party.
} 


$$
\text { Party policy distance }=\left|A_{i}-X_{i}\right|
$$

where $A_{i}$ is the position of the mean voter on the leftright dimension, and $X_{i}$ is the mean perceived position of party $X .^{13}$

In order to test the two hypotheses, we first estimate ordinary least squares (OLS) regression models for advanced and new democracies separately. The specification of these models is as follows:

$$
\begin{gathered}
\text { Normalized vote share }=\beta_{1}+\beta_{2}[\text { Party policy distance }] \\
+e,
\end{gathered}
$$

H1: $\beta_{2}<0$, for parties in established democracies,

H2: $\beta_{2}>0$, for parties in postcommunist democracies, where Party policy distance equals the left-right distance between the party's position and the mean voter position.

In alternative analyses, we replace the party policy distance by relative party policy distance in order to account for variation in the dispersion of parties along the left-right scale across different countries. This measure normalizes a party's policy distance from the mean voter position to the average policy distance of all of the parties competing in the same election. ${ }^{14}$ It is calculated by dividing a party's policy distance by the average party policy distance of the given election:

$$
\text { Relative party policy distance }=\frac{\left|A_{j}-X_{i j}\right|}{\sum_{i}\left|A_{j}-X_{i j}\right| / n} .
$$

Our analysis encompasses 335 observations of party policy distances and vote shares in 31 democracies, including 90 observations from the 10 postcommunist democracies for which CSES data are available: Albania, Bulgaria, Croatia, Czech Republic, Hungary,

\footnotetext{
${ }^{13}$ Several studies suggest that the patterns of ideological structuring underlying the left-right scale may differ between Eastern and Western Europe (e.g., Evans and Whitefield 1993) as well as across countries and time (Evans and Whitefield 1998; Harbers, de Vries, and Steenbergen 2013; Linzer 2008). We address this issue in the supplementary appendix (p. S1) and conclude that (1) the general understanding of left-right is similar across CEE and WE (see also Rohrschneider and Whitefield 2012) and (2) our results are not likely to be affected by any cross-national differences in the meaning of left-right.

${ }^{14}$ Party policy distance can also be measured relative to the dispersion of the voter distribution (i.e., the standard deviation of respondents' left-right self-placements in the country) in order to account for whether parties compete in compact or dispersed electorates (see Alvarez and Nagler 2004). Using this measure does not change the results.
}

Poland, Romania, Russia, Ukraine, and Slovenia. The supplementary appendix presents the complete set of countries, election years, political parties, mean voter positions, parties' left-right positions, and party vote shares included in the empirical analyses. Table 1 reports the means and standard deviations of the observed values of the variables in our data set.

Our cross-sectional analysis pools 194 parties; each observed an average of 1.7 elections. For postcommunist countries, there are 67 parties; each observed an average of 1.3 elections. While most parties are observed only once in the analysis, the error terms for the parties competing in each election are unlikely to be independent. Namely, if a party manages to receive a greater than expected vote share in an election, other parties in the same election will have lower than expected vote shares. Thus the errors for all parties in the same election will be correlated. We address this concern through the estimation of heteroskedastic robust standard errors clustered by election. If we estimate robust standard errors clustered on party or country, our substantive results remain unchanged for all of the analyses reported below. Additionally, the results remain unchanged if we control for country-specific effects. ${ }^{15}$

\section{Results}

Table 2 reports the parameter estimates for Equation (3), which estimates popular support for the parties that are included in the empirical analysis, stratified by type of democracy (established and postcommunist). The parameter estimates in Table 2 support the Established Parties Hypothesis. In Columns 1-2 of Table 2, the coefficients for party policy distance are negative and statistically significant indicating that as a party's policy distance increases, its vote share decreases. Thus, moderate party positioning and popular support appear to be linked across established democracies in our analysis.

The results from Columns 3-4 in Table 2 also confirm the Postcommunist Parties Hypothesis. Each of the parameter estimates for party policy distance is positive and reaches statistical significance. These estimates indicate that in postcommunist countries, those parties that are perceived to be farther away from the center of the voter distribution are likely to receive more votes than their centrist counterparts.

\footnotetext{
${ }^{15}$ These analyses are available in Tables S2e-S4g of the supplementary appendix.
} 
Table 1 Descriptive Statistics for the Dependent and Independent Variables

\begin{tabular}{cccc}
\hline & All & & \\
& Countries & Postcommunist & Advanced \\
\hline Normalized vote & 90.31 & 92.36 & 89.56 \\
share & $(54.16)$ & $(59.20)$ & $(52.30)$ \\
Party policy & 1.76 & 1.88 & 1.71 \\
distance & $(1.06)$ & $(1.23)$ & $(.98)$ \\
Relative party & 1.00 & 1.00 & 1.00 \\
distance & $(.56)$ & $(.61)$ & $(.54)$ \\
Proportion & 82.30 & 75.82 & 84.68 \\
willing to & $(11.52)$ & $(13.95)$ & $(9.46)$ \\
place party & & & \\
Standard & 2.11 & 2.34 & 2.03 \\
deviation of & $(.49)$ & $(.46)$ & $(.47)$ \\
placements & & & \\
\hline
\end{tabular}

Note: Table entries are mean values with respective standard deviations in parentheses. The variables are defined in Equations (1), (2), and (4) in the text. The complete set of countries, election years, political parties, mean voter positions, parties' left-right positions, and party vote shares included in the empirical analyses are presented in the online supplementary information.

The central implication of this result is that it is the ideological distinctiveness along the left-right dimension that contributes to the electoral success of parties in postcommunist systems.

There are three additional notable features about the effects that we report in Columns 1 and 3 and in Columns 2 and 4. First, although the coefficients are signed in the opposite direction, they are nearly identical in magnitude $(-10.12$ and $10.01 ;-18.10$ and 20.17). Second, the differences between the coefficients estimated for established democracies and postcommunist democracies are statistically significant. ${ }^{16}$ Third, the effects are substantively large. A party competing in a postcommunist system with three competitive parties that is three units away from the mean voter position will gain, on average, 6.66 percentage points more than a centrist party which is only one unit from the mean voter position. In a four-party system, the more extreme party under this scenario gains on average five percentage points more than the centrist competitor. ${ }^{17}$

\footnotetext{
${ }^{16}$ The parameter estimates of an interaction model specification were estimated to confirm this finding.

${ }^{17}$ In alternative analyses, reported in the supplementary appendix (Tables S5h-S4l, pp. S17-S21), we also control for the effect of incumbency and the economy and find similar results regardless of whether incumbents are defined as members of the governing coalition at the time of the election or as communist successor parties. Additionally, controlling for membership size or the extensiveness of parties' presence in local communities (Tavits 2013) did not alter the results for the postcommunist sample.
}

To further illustrate the central conclusion from the above analyses, consider Figure 1 that plots the policy distances of parties along the $x$-axis and their absolute vote percentages along the $y$-axis (these are not normalized vote percentages). ${ }^{18}$ The slope estimates of the "best-fit" lines for the postcommunist democracies are distinctly positive $(B=2.54 ; p<0.05)$, indicating that parties in postcommunist democracies tend to receive greater vote shares as their policy distance (or distinctiveness) from the center of the voter distribution increases. Alternatively, the negative slope-lines for parties in advanced democracies $(B=-2.37$; $p<0.001)$ suggest that these parties benefit from adopting policies closer to the center of the voter distribution.

We have here focused on a single left-right policy dimension. However, previous research (Kriesi et al. 2008; Marks et al. 2006) highlights the role of an additional noneconomic dimension of party competition in at least some Western European countries. A unidimensional analysis could thus potentially bias our results. Benoit and Laver (2006) have identified the following countries in our datasets as the ones where political competition revolves primarily around a single left-right dimension: Britain, the Netherlands, Italy, Norway, Iceland, and Switzerland. We estimated separate models excluding these countries from the sample of advanced democracies. The results (presented in Table S2m of the supplementary appendix [see also Table S3m]) hold for the multidimensional countries, suggesting that we are not biasing our results by omitting these additional dimensions.

Note that, because we do not present dynamic analyses (i.e., we do not study the effect of change in party positions), our results do not necessarily imply that political parties will, over time, converge on the mean voter position in established democracies and rush to the extremes in postcommunist ones. Position change may or may not be advantageous for the party depending on, for example, the credibility of the change (see Tavits 2007) or whether the change corresponds with changing public opinion (see Ezrow 2005). Indeed, previous research reports only very small and lagged

\footnotetext{
${ }^{18}$ To ensure that the substantive conclusions are not affected by our measure of the dependent variable, we estimated additional models using party's absolute vote share as the dependent variable. For these analyses, it remains necessary to control for the number of competitors. We used two measures of "effective number of parties" based on Laakso and Taagepera (1979): one based on party vote shares, and one based on seat shares. We also used a measure based on the number of parties receiving over $5 \%$ of the vote. Our results remain unchanged regardless of the measure used (see Tables S2a-S4b of the supplementary appendix).
} 
Table 2 The Effect of Party Policy Distance on Normalized Vote Share

\begin{tabular}{|c|c|c|c|c|}
\hline & \multicolumn{2}{|c|}{ Advanced Democracies } & \multicolumn{2}{|c|}{ Postcommunist Democracies } \\
\hline & (1) & $(2)$ & (3) & $(4)$ \\
\hline Party policy distance & $\begin{array}{c}-10.12^{\star \star \star} \\
(3.13)\end{array}$ & & $\begin{array}{l}10.01^{\star} \\
(5.19)\end{array}$ & \\
\hline Relative party policy distance & & $\begin{array}{c}-18.10^{\star * *} \\
(6.43)\end{array}$ & & $\begin{array}{c}20.17^{\star} \\
(11.06)\end{array}$ \\
\hline Constant & $\begin{array}{c}106.88^{\star * *} \\
(5.41)\end{array}$ & $\begin{array}{c}107.66^{\star * *} \\
(6.39)\end{array}$ & $\begin{array}{l}73.59^{\star * *} \\
(12.57)\end{array}$ & $\begin{array}{l}72.20^{\star * *} \\
(12.66)\end{array}$ \\
\hline $\mathrm{N}$ & 245 & 245 & 90 & 90 \\
\hline $\mathrm{R}^{2}$ & .04 & .03 & .04 & .04 \\
\hline
\end{tabular}

Note: Table entries are unstandardized regression coefficients with standard errors (clustered on election) in parentheses. The dependent variable is Normalized vote share, which is calculated as the party's vote share multiplied by the number of competitive parties in the election (see Equation 1 in the text). Relative party policy distance is described in Equation (4) in the text. ${ }^{\star} p<.10 ;{ }^{* *} p<.05 ;{ }^{* *} p<.01$, two-tailed test.

electoral benefits for parties that moderated their positions in established democracies (Adams and Somer-Topcu 2009). Furthermore, we performed an alternative set of analyses using parties' squared proximities to the mean voter position as the measure of party policy distance in order to see whether parties' vote shares increase more rapidly in response to increasingly moderate (extreme) positions in advanced (postcommunist) democracies. The results suggested this not to be the case.

\section{Testing the Mechanism (I): Party Policy Distance and Voter Certainty}

According to our theory, the central finding (i.e., that, in postcommunist countries, parties benefit from taking more extreme policy positions) depends on the relationship between party policy distance and voter certainty about parties' positions. Our argument suggests that this relationship is different for new democracies compared to the established ones. Specifically, we argued that, in

\section{FIgURe 1 Party Policy Distance and Vote Share}

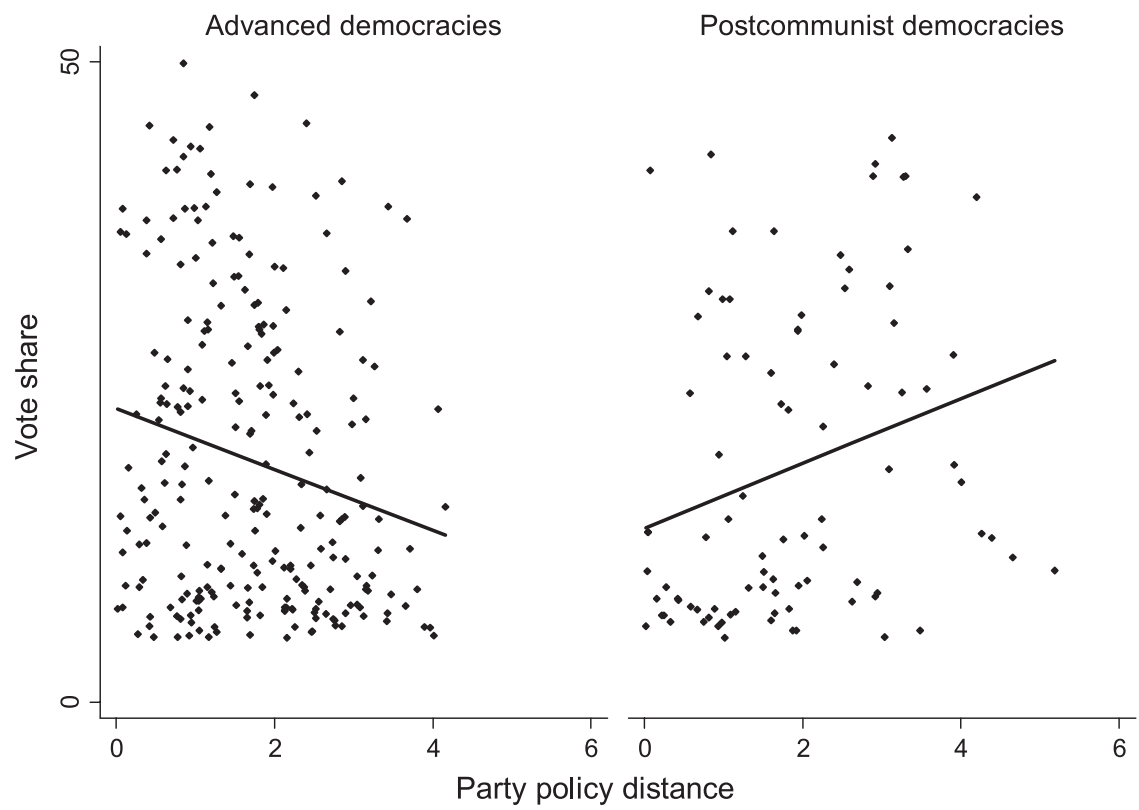

Note: The figure presents party policy distances from the mean voter position and vote shares for parties in advanced and postcommunist democracies, including line of best fit. The data are based on respondents' perceptions of parties' left-right policy positions from the Comparative Study of Electoral Systems (CSES). 
new democracies, extremism enhances voter certainty about party position. Citizens in established democracies, on the other hand, are likely to be relatively more certain about policy position of all, including the moderate parties.

We can provide a direct test of this expectation. To measure voter certainty about party positions, we rely on the CSES question (also described in the previous section) that asks respondents in each country to place each of their significant national parties on a left-right scale that ranges from 0 (extreme left) to 10 (extreme right). We construct two alternative and relatively straightforward measures of voter certainty. First, we calculate the proportion of respondents that were willing to place the party on the left-right scale (variable labeled proportion willing to place the party). Second, we calculate the standard deviation of respondents' left-right placements of the party's position (variable labeled standard deviation of citizen placements). ${ }^{19}$

We use OLS with robust standard errors clustered on party to estimate the effect of party policy distance on voter certainty about policy position. The results presented in Table 3 support our expectation that party policy distance is more closely associated with voter certainty in the postcommunist countries than in established democracies. In Column 1 of Table 3, the coefficient for party policy distance is positive and statistically significant for the postcommunist observations, indicating that as party policy distance increases, the proportion of respondents that are willing to place the party on the left-right scale also increases. Similarly, the coefficient in Column 2, which estimates the effect of party policy distance on the standard deviation of citizen placements, is negative and statistically significant, which indicates that as party policy distance increases, citizens are, on average, more consistent in their placement of that party. In sum, in the postcommunist context, extreme party positioning appears to be associated with increased voter certainty about the party's left-right position.

The results for the established democracies are weak and mixed. In Column 3, the coefficient for the party policy distance is positive and statistically significant suggesting that as party policy distance increases, more people are willing to place the party on the left-right scale. However, the coefficient (1.27) is more than three times smaller than was the case with parties in postcommunist countries (4.62). Furthermore, in Column 4, the coefficient for party

\footnotetext{
${ }^{19}$ The correlation coefficient is $-0.45(p<0.01)$ between the two measures of voter certainty.
}

policy distance is only -0.03 (compared to -0.11 in the postcommunist countries) and not statistically significant. The evidence supports the existence of a weaker relationship between party policy distance and voter certainty in established democracies than in postcommunist democracies.

\section{Testing the Mechanism (II): Voter Certainty and Vote Share}

Recall that our theoretical argument also suggests that voters are reluctant to support parties whose positions are uncertain. Note that unlike the other relationships that we proposed and tested, we do not expect this relationship to differ across types of democracies; rather, we argued in the theory section that uncertainty repels voters, in general. Accordingly, we test this expectation by pooling all observations and using our two measures of voter certainty about party policy position and normalized vote share. To estimate the models, we use OLS with robust standard errors clustered on election. ${ }^{20}$ The results are presented in Table 4.

We find strong support for this proposition based on one of the measures of voter certainty: proportion willing to place the party. In Column 1, the coefficient for this variable is positive and statistically significant, indicating that when respondents are more willing to place the party on an ideological continuum, the party is likely to gain greater vote share than parties that citizens are less willing to place. In Column 2, the coefficient which estimates the effect of standard deviation of citizen placements is negative (as expected), but it remains statistically insignificant. ${ }^{21}$ Recall that the correlation coefficient between the two measures of voter certainty is only -0.45 . It is, therefore, not surprising that the two measures produce somewhat different results. One might also argue that proportion willing to place the party is a stronger measure of uncertainty because it is more likely to indicate that voters truly do not know how to place the party. The standard deviation measure, on the other hand, captures the extent to which citizens differ in their placements. This may not always indicate voter uncertainty because some voters may be certain about

\footnotetext{
${ }^{20}$ The substantive results remain unchanged if we use absolute vote share as the dependent variable and/or robust standard errors clustered on party.

${ }^{21}$ The substantive findings are similar when we split the sample into advanced and postcommunist democracies and run the analyses separately for both groups, although the result for the postcommunist sample is statistically weaker.
} 
Table 3 Regression Coefficients for Party Policy Distance When Estimating Voter Certainty

\begin{tabular}{|c|c|c|c|c|}
\hline & \multicolumn{2}{|c|}{ Postcommunist Democracies } & \multicolumn{2}{|c|}{ Advanced Democracies } \\
\hline & $\begin{array}{l}\text { Proportion Willing } \\
\text { to Place Party (1) }\end{array}$ & $\begin{array}{l}\text { Standard Deviation } \\
\text { of Placements }(2)\end{array}$ & $\begin{array}{l}\text { Proportion Willing } \\
\text { to Place Party }(3)\end{array}$ & $\begin{array}{c}\text { Standard Deviation } \\
\text { of Placements }(4)\end{array}$ \\
\hline \multirow[t]{2}{*}{ Party policy distance } & $4.62^{\star * *}$ & $-.11^{\star *}$ & $1.27^{\star}$ & -.03 \\
\hline & $(1.18)$ & $(.05)$ & $(.71)$ & $(.04)$ \\
\hline \multirow[t]{2}{*}{ Constant } & $67.16^{\star * *}$ & $2.54^{\star * \star}$ & $82.50^{\star * *}$ & $2.08^{\star * *}$ \\
\hline & $(3.33)$ & $(.11)$ & $(1.46)$ & $(.09)$ \\
\hline $\mathrm{N}$ & 90 & 90 & 245 & 245 \\
\hline $\mathrm{R}^{2}$ & .17 & .08 & .02 & .00 \\
\hline
\end{tabular}

Note: Table entries are unstandardized regression coefficients with standard errors (clustered on party) in parentheses. Dependent variables are noted in column headings.

${ }^{*} p<.10 ;{ }^{* *} p<.05 ;{ }^{* *} p<.01$, two-tailed test.

their own placement of a party even if they place it far away from its "actual" position. All in all, we believe that there is at least some empirical support for our claim that uncertainty about party placements repels voters.

Although we find considerable support for our central argument and the causal mechanism, there is a plausible alternative explanation that we have not yet explored fully. Specifically, we found that incumbents (i.e., parties in government at the time of the election) in postcommunist democracies are more extreme than the opposition (for the former, the average party policy distance is 2.66 , for the latter, it is only 1.69; the difference is statistically significant at the $1 \%$ level). It is, therefore, possible that our results are driven by incumbency and not by extremism. There are several relationships that incumbency may

\section{Table 4 The Effect of Voter Certainty on Normalized Vote Share, All Countries}

\begin{tabular}{|c|c|c|}
\hline & $\begin{array}{l}\text { (1) Proportion } \\
\text { Willing } \\
\text { to Place Party }\end{array}$ & $\begin{array}{l}\text { (2) Standard } \\
\text { Deviation of } \\
\text { Placements }\end{array}$ \\
\hline $\begin{array}{l}\text { Proportion willing to } \\
\text { place party }\end{array}$ & $\begin{array}{l}.56^{\star \star} \\
(.25)\end{array}$ & \\
\hline $\begin{array}{l}\text { Standard deviation of } \\
\text { placements }\end{array}$ & & $\begin{array}{l}-2.38 \\
(5.10)\end{array}$ \\
\hline Constant & $\begin{array}{l}44.17^{\star \star} \\
(22.13)\end{array}$ & $\begin{array}{l}95.34^{* * *} \\
(9.66)\end{array}$ \\
\hline $\mathrm{N}$ & 335 & 335 \\
\hline $\mathrm{R}^{2}$ & .014 & .001 \\
\hline \multicolumn{3}{|c|}{$\begin{array}{l}\text { Note: Table entries are unstandardized regression coefficients with } \\
\text { standard errors (clustered on election) in parentheses. The de- } \\
\text { pendent variable is Normalized vote share, which is calculated as the } \\
\text { party's vote share multiplied by the number of competitive parties } \\
\text { in the election (see Equation } 1 \text { in the text). } \\
{ }^{\star} p<.10 ;{ }^{* *} p<.05 ;{ }^{* * *} p<.01 \text {, two-tailed test. }\end{array}$} \\
\hline
\end{tabular}

influence: (a) between policy distance and vote share (Table 2); (b) policy distance and certainty (Table 3); and (c) certainty and vote share (Table 4). Accordingly, we include in the supplementary appendix (Tables S5h-S4l), results for each of these relationships, controlling directly for incumbency (see also footnote 17). All substantive effects remain unchanged in those analyses, regardless of whether incumbency is defined by government membership or communist successor party status.

In sum, we found that, while in advanced democracies parties benefit electorally from policy moderation, in new democracies they benefit from taking extreme policy positions. We further found that voters are reluctant to support parties whose positions they are uncertain about and that extreme policy positioning helps increase voter certainty about party positions in postcommunist democracies more than in the established ones. ${ }^{22}$ Taken together, these findings offer, in line with our theoretical reasoning, a plausible explanation for why extreme parties perform well in national elections in the new democracies of postcommunist Europe: it is because

\footnotetext{
${ }^{22}$ One might be concerned that voter certainty about party positions is endogenous to party size. To address this, we controlled for party size in the analyses reported in Table 3 (see Table S3n in the supplementary appendix). The effect of party policy distance remained unchanged and the coefficient for party size was not significant, suggesting that voter certainty about party placement does not depend on party size. The supplementary appendix also presents results of individual-level analyses (see pp. S2-S7), which indicate that (a) a respondent is more certain about the placement of a party the more extreme its position, regardless of the party size, and (b) a respondent is more likely to vote for a party the more certain the voters are, on average, about the placement of that party. The results of these additional tests alleviate concerns of endogeneity; we do acknowledge, however, that given the observational data, the endogeneity problem cannot be solved completely.
} 
voters are more certain about the policy stances of these parties. Moderate parties, on the other hand, perform poorly because voters are more likely to be uncertain about where these parties stand on policy.

\section{Conclusion}

In this study, we have argued that (1) uncertainty about party positions repels voters, (2) in new democracies, extreme positioning is especially effective in reducing voter uncertainty about party positions because, unlike in advanced democracies, other cues about party positions are lacking, and (3) if (1) and (2) hold, we should observe that in new democracies, noncentrist policy positions are electorally more beneficial than centrist ones. In accord with this argument, we report several remarkable findings. First, we show that in established democracies, moderate parties gain more votes than their extreme competitors. Second, in postcommunist countries, by contrast, we find the exact opposite: extreme parties gain systematically more votes than their moderate competitors. Finally, we report a third set of findings in an attempt to explain this remarkable difference between electoral competition in established and postcommunist democracies. These findings suggest that voters in all democracies are reluctant to support parties whose positions they are uncertain about. Furthermore, in postcommunist democracies, citizens are more certain about the positions of extreme than moderate parties. By contrast, this relationship is weak or nonexistent for established democracies. This suggests that extreme parties do well in new democracies because voters are more certain about their left-right ideological positions than they are of the positions of moderate parties.

We believe that the results that we report-between party policy distance, voter certainty, and vote sharerepresent a significant step forward and that they have important implications for our understanding of the differences in electoral competition between established and new democracies. One of these implications is that extreme parties perform well in transitioning democracies because these parties present clear policy signals to their electorates. While extreme party competition can be viewed positively in the sense that parties are taking clear stances on issues, it is simultaneously less representative of the median voter position that is privileged by many theorists of democracy (McDonald and Budge 2005; see also Powell 2000). Our study suggests that if the uncertainty of the political landscape decreases in newer democracies, the incentives for parties to present extreme positions will decrease. Finally, while we have identified important aggregate patterns that enhance our understanding of party competition in established and postcommunist countries, much more work needs to be done at the individual level to fully explain our results.

\section{Acknowledgments}

The authors would like to thank Jim Adams, Garrett Glasgow, Seth Jolly, and Tom Scotto for insightful comments on this article. An earlier version was presented at the 2013 annual meeting of the Midwest Political Science Association.

\section{References}

Adams, James. 2001. Party Competition and Responsible Party Government: A Theory of Spatial Competition Based upon Insights from Behavioral Voting Research. Ann Arbor: University of Michigan Press.

Adams, James, and Samuel Merrill, III. 1999. "Party Policy Equilibrium for Alternative Spatial Voting Models: An Application to the Norwegian Storting." European Journal of Political Research 36 (2): 35-55.

Adams, James, and Samuel Merrill, III. 2000. "Spatial Models of Candidate Competition and the 1988 French Presidential Election: Are Presidential Candidates Vote-Maximizers?" Journal of Politics 62 (3): 729-56.

Adams, James, and Zeynep Somer-Topcu. 2009. "Moderate Now, Win Votes Later: The Electoral Consequences of Parties' Policy Shifts in Twenty-Five Postwar Democracies." Journal of Politics 71 (2): 678-92.

Alesina, Alberto, and Alex Cukierman. 1990. "The Politics of Ambiguity." Quarterly Journal of Economics 105 (4): 829-50.

Alesina, Alberto, and Richard Holden. 2008. Ambiguity and Extremism in Elections. NBER Working Paper No. 14143.

Alvarez, R. Michael. 1998. Information and Elections. Ann Arbor: University of Michigan Press.

Alvarez, R. Michael, and Jonathan Nagler. 2004. "Party System Compactness: Consequences and Measures.” Political Analysis 12 (1): 46-62.

Alvarez, R. Michael, Jonathan Nagler, and Shaun Bowler. 2000a. "Issues, Economics, and the Dynamics of Multiparty Elections: The 1997 British General Election." American Political Science Review 42 (1): 55-96.

Alvarez, R. Michael, Jonathan Nagler, and Jennifer R. Willette. 2000b. "Measuring the Relative Impact of Issues and the Economy in Democratic Elections." Electoral Studies 19 (2-3): 237-53.

Ansolabehere, Stephen, James Snyder, and Charles Stewart. 2001. "Candidate Positioning in U.S. House Elections." American Journal of Political Science 45 (1): 136-59.

Bartels, Larry M. 1986. "Issue Voting Under Uncertainty: An Empirical Test.” American Journal of Political Science 30 (4): 709-28.

Benoit, Kenneth, and Michael Laver. 2006. Party Policy in Modern Democracies. London: Routledge. 
Bernhardt, Daniel M., and Daniel E. Ingberman. 1985. "Candidate Reputation and the Incumbency Effect." Journal of Public Economics 27 (1): 47-67.

Birch, Sarah. 2003. Electoral Systems and Political Transformation in Post-Communist Europe. Basingstoke: Palgrave-Macmillan.

Budge, Ian. 1994. "A New Theory of Party Competition: Uncertainty, Ideology, and Policy Equilibria Viewed Temporally and Comparatively." British Journal of Political Science 24 (4): 443-67.

Budge, Ian, Lawrence Ezrow, and Michael D. McDonald. 2010. "Ideology, Party Factionalism and Policy Change: An Integrated Dynamic Theory." British Journal of Political Science 40 (4): 781-804.

Burden, Barry. 2001. Choices and Echoes in U.S. House Elections. Presented at the Annual Meeting of the Public Choice Society, San Antonio, TX.

Campbell, James E. 1983. "The Electoral Consequences of Issue Ambiguity: An Examination of the Presidential Candidates' Issue Positions from 1968 to 1980." Political Behavior 5 (3): 277-91.

Canes-Wrone, Brandice, David W. Brady, and John F. Cogan. 2002. "Out of Step, Out of Office: Electoral Accountability and House Members' Voting." American Political Science Review 96 (1): 127-40.

Clark, Michael. 2009. "Valence and Electoral Outcomes in Western Europe, 1976-1998.” Electoral Studies 28 (1): 111-22.

Cox, Gary. 1990. "Centripetal and Centrifugal Incentives in Electoral Systems." American Journal of Political Science 34 (4): 905-35.

Dalton, Russell J. 2008. “The Quantity and the Quality of Party Systems Party System Polarization, Its Measurement, and Its Consequences.” Comparative Political Studies 41 (7): 899-920.

Dow, Jay K. 2001. “A Comparative Spatial Analysis of Majoritarian and Proportional Elections." Electoral Studies 20 (1): 109-25.

Dow, Jay K. 2011. "Party-System Extremism in Majoritarian and Proportional Electoral Systems." British Journal of Political Science 41 (2): 341-61.

Downs, Anthony. 1957. An Economic Theory of Democracy. New York: Harper.

Druckman, James N., and Andrew Roberts. 2007. "Communist Successor Parties and Coalition Formation in Eastern Europe." Legislative Studies Quarterly 32 (1): 5-31.

Enelow, James, and Melvin J. Hinich. 1984. The Spatial Theory of Voting. Cambridge: Cambridge University Press.

Erikson, Robert, Michael MacKuen, and James Stimson. 2002. The Macro Polity. Cambridge: Cambridge University Press.

Evans, Geoffrey. 2006. "The Social Bases of Political Divisions in Post-Communist Eastern Europe." Annual Review of Sociology 32: $245-70$.

Evans, Geoffrey, and Stephen Whitefield. 1993. "Identifying the bases of party competition in Eastern Europe." British Journal of Political Science 23 (4): 521-48.

Evans, Geoffrey, and Stephen Whitefield. 1998. "The Evolution of the Left and Right in Post-Soviet Russia." Europe-Asia Studies 50 (6): 1023-42.

Evans, Geoffrey, and Stephen Whitefield. 2000. "Explaining the Formation of Electoral Cleavages in Postcommunist Democracies." In Elections in Central and Eastern Europe: The First Wave, eds. Hans-Dieter Klingemann, Ekkehard Mochman, and Kenneth Newton. Berlin: Sigma, 36-68.

Ezrow, Lawrence. 2005. "Are Moderate Parties Rewarded in Multiparty Systems? A Pooled Analysis of Western European
Elections, 1984-1998." European Journal of Political Research 44 (6): 881-98.

Ezrow, Lawrence. 2010. Linking Citizens and Parties: How Electoral Systems Matter for Political Representation. Oxford: Oxford University Press.

Ezrow, Lawrence, Margit Tavits, and Jonathan Homola. N.d. "Voter Polarization, Strength of Partisanship, and Support for Extremist Parties." Comparative Political Studies. Forthcoming.

Fortunato, David, and Randolph T. Stevenson. 2013. "Perceptions of Partisan Ideologies: The Effect of Coalition Participation." American Journal of Political Science 57 (2): 459-77.

Franklin, Charles H. 1991. "Eschewing Obfuscation? Campaigns and the Perception of U.S. Senate Incumbents." American Political Science Review 85 (4): 1193-1214.

Groseclose, Tim. 2001. "A model of Candidate Location When One Candidate Has a Valence Advantage." American Journal of Political Science 45 (4): 862-86.

Grzymala-Busse, Anna. 2001. "Coalition Formation and the Regime Divide in New Democracies: East Central Europe." Comparative Politics 34 (1): 85-104.

Grzymala-Busse, Anna. 2006. "Authoritarian Determinants of Democratic Party Competition.” Party Politics 12 (3): 415-37.

Harbers, Imke, Catherine E. de Vries, and Marco R. Steenbergen. 2013. "Attitude Variability Among Latin American Publics: How Party System Structuration Affects Left/Right Ideology." Comparative Political Studies 46 (8): 947-67.

Hinich, Melvin J., and Michael C. Munger. 1994. Ideology and the Theory of Political Choice. Ann Arbor: University of Michigan Press.

Hinich, Melvin J., and Michael C. Munger 1997. Analytical Politics. Cambridge: Cambridge University Press.

Ingberman, Daniel E. 1989. "Reputational Dynamics in Spatial Competition." Journal of Mathematical and Computer Modeling 12 (4-5): 479-96.

Kitschelt, Herbert. 2000. "Linkages between Citizens and Politicians in Democratic Polities." Comparative Political Studies 33 (6-7): 845-79.

Koch, Jeffrey W. 2003. "Being Certain Versus Being Right: Citizen Certainty and Accuracy of House Candidates' Ideological Orientations." Political Behavior 25 (3): 221-46.

Kriesi, Hanspeter, Edgar Grande, Romain Lachat, Martin Dolezal, Simon Bornschier, and Timotheos Frey. 2008. West European Politics in the Age of Globalization. Cambridge: Cambridge University Press.

Laakso, Markku, and Rein Taagepera. 1979. "“Effective' Number of Parties: A Measure with Application to West Europe." Comparative Political Studies 12 (1): 3-27.

Lachat, Romain. 2008. "The Impact of Party Polarization on Ideological Voting." Electoral Studies 27 (4): 687-98.

Laver, Michael. 2005. "Policy and the Dynamics of Political Competition." American Political Science Review 99 (2): 263-81.

Lewis-Beck, Michael. 1988. Economics and Elections. Ann Arbor: University of Michigan Press.

Lin, Tse-Min, James Enelow, and Han Dorussen. 1999. "Equilibrium in Multicandidate Probabilistic Spatial Voting." Public Choice 98 (1): 59-82.

Linzer, Drew. 2008. The Structure of Mass Ideology and its Consequences for Democratic Governance. PhD diss. University of California, Los Angeles.

Mainwaring, Scott, and Timothy R. Scully. 1995. Building Democratic Institutions: Party Systems in Latin America. Stanford, CA: Stanford University Press. 
Mair, Peter, and Ingrid van Biezen. 2001. "Party Membership in Twenty European Democracies, 1980-2000." Party Politics 7 (1): 5-21.

Marks, Gary, Liesbet Hooghe, Moira Nelson, and Erica Edwards. 2006. "Party Competition and European Integration in the East and West: Different Structure, Same Causality." Comparative Political Studies 39 (1): 155-75.

McDonald, Michael D., and Ian Budge. 2005. Elections, Parties, Democracy: Conferring the Median Mandate. Oxford: Oxford University Press.

Nagel, Jack, and Christopher Wlezien. 2010. "Centre-Party Strength and Major-Party Divergence in Britain, 1945-2005." British Journal of Political Science 40 (2): 279-304.

O'Donnell, Guillermo, and Philippe C. Schmitter. 1986. Transitions from Authoritarian Rule: Tentative Conclusions about Uncertain Democracies. Baltimore: Johns Hopkins University Press.

Page, Benjamin I. 1976. "The Theory of Political Ambiguity." American Political Science Review 70 (3): 742-52.

Page, Benjamin I. 1978. Choices and Echoes in Presidential Elections: Rational Man and Electoral Democracy. Chicago: University of Chicago Press.

Powell, G. Bingham. 2000. Elections as Instrument of Democracy: Majoritarian and Proportional Visions. New Haven, CT: Yale University Press.

Powell, G. Bingham, and Guy D. Whitten. 1993. “A Cross-National Analysis of Economic Voting: Taking Account of Political Context." American Journal of Political Science 37 (2): 391-414.

Powell, Eleanor Neff, and Joshua A. Tucker. 2013. "Revisiting Electoral Volatility in Post-Communist Countries: New Data, New Results and New Approaches." British Journal of Political Science. doi:10.1017/S0007123412000531 (accessed on November 11, 2013).

Rabinowitz, George, and Stuart Elaine Macdonald. 1989. "A Directional Theory of Issue Voting." American Political Science Review 83 (1): 93-121.

Rohrschneider, Robert, and Stephen Whitefield. 2009. "Understanding Cleavages in Party Systems: Issue Position and Issue Salience in 13 Post-Communist Democracies." Comparative Political Studies 42 (2): 280-313.

Rohrschneider, Robert, and Stephen Whitefield. 2012. The Strain of Representation: How Parties Represent Diverse Voters in Western and Eastern Europe. Oxford: Oxford University Press.

Rose, Richard. 1995. "Mobilizing Demobilized Voters in Post-Communist Societies." Party Politics 1 (4): 549-63.

Rose, Richard, and William Mishler. 2010. "A Supply-Demand Model of Party-System Institutionalization: The Russian Case." Party Politics 16 (6): 801-21.
Schofield, Norman. 2004. "Equilibrium in the Spatial Valence Model of Politics." Journal of Theoretical Politics 16 (3/4): 447-81.

Schofield, Norman, and Itai Sened. 2006. Multiparty Democracy: Parties, Elections, and Legislative Politics. Cambridge: Cambridge University Press.

Schofield, Norman, Itai Sened, and David Nixon. 1998a. "Nash Equilibrium in Multiparty Competition with 'Stochastic' Voters." Annals of Operations Research 84: 3-27.

Schofield, Norman, Andrew Martin, Kevin Quinn, and David Nixon. 1998b. "Multiparty Electoral Competition in the Netherlands and Germany: A Model Based on Multinomial Probit." Public Choice 97 (3): 257-93.

Tavits, Margit. 2005. "The Development of Stable Party Support: Electoral Dynamics in Post-Communist Europe." American Journal of Political Science 49 (2): 283-98.

Tavits, Margit. 2007. "Principle vs. Pragmatism: Policy Shifts and Political Competition." American Journal of Political Science 51 (1): 151-65.

Tavits, Margit. 2013. Post-Communist Democracies and Party Organization. New York: Cambridge University Press.

Tavits, Margit, and Taavi Annus. 2006. "Learning to Make Votes Count: The Role of Democratic Experience." Electoral Studies 25 (1): 72-90.

Tavits, Margit, and Natalia Letki. 2009. "When Left is Right: Party Ideology and Policy in Post-Communist Europe." American Political Science Review 103 (4): 555-69.

Tomz, Michael, and Robert P. van Houweling. 2009. "The Electoral Implications of Candidate Ambiguity." American Political Science Review 103 (1): 83-98.

Tzelgov, Eitan. 2011. "Communist Successor Parties and Government Survival in Central Eastern Europe." European Journal of Political Research 50 (4): 530-58.

Van Biezen, Ingrid. 2003. Political Parties in New Democracies: Party Organization in Southern and East-Central Europe. Basingstoke, UK: Palgrave Macmillan.

Lawrence Ezrow is a Professor of Government at the University of Essex, Colchester, UK.

Jonathan Homola is a Ph.D. Candidate at the Department of Political Science, Washington University in St. Louis, St. Louis, MO 63130.

Margit Tavits is an Associate Professor at the Department of Political Science, Washington University in St. Louis, St. Louis, MO 63130. 